\title{
MIDWIVES AND HERBAL REMEDIES: THE SUSTAINABLE ETHNOSCIENCE
}

\section{Kartini Aboo Talib@ Khalid ${ }^{1 *}$ and Nurshuhada Mohamed ${ }^{2}$}

${ }^{1}$ Institute of Ethnic Studies (KITA), Universiti Kebangsaan Malaysia, Selangor, MALAYSIA

${ }^{2}$ Pusat Pengajian Pembangunan Sosial \& Ekonomi, Universiti Malaysia Terengganu, Terengganu, MALAYSIA

*Corresponding author: k_khalid@ukm.edu.my

Published online: 15 April 2020

To cite this article: Kartini Aboo Talib@ Khalid and Nurshuhada Mohamed. 2020. Midwives and herbal remedies: The sustainable ethnoscience. Kajian Malaysia 38(Supp.1): 109-131. https://doi.org/10.21315/km2020.38.s1.7

To link to this article: $\mathrm{https} / /$ doi.org/10.21315/km2020.38.s1.7

\section{ABSTRACT}

The traditional Malay practices of pre and postnatal care have been fascinating to help understand women's health and reproductive role. Women within midwives and midwifery contexts made their status recognised back in the ancient practice. The ethnoscience methods about women's health have been the centre of discussion way back in the Aztec, Mayan and Egyptian civilisations, yet the topic never gets exhausted. The ethnographic research on midwives conducted in Terengganu in the 1980s and other new literature provided a variation to the study of midwives. This article attempts to revisit the observation of midwives on herbal remedies and other healing processes after a gap of more than 30 years. The question remains whether or not this traditional practice, including herbal intake for diet, bath and massage is sustained in this millennium society. Also, this article analyses the factors and reasons for the persistence of such methods. This research utilises participant observation and intensive interviews with midwives from the west coast of Malaysia. A similar pattern of answers provides essential themes on the utilisation of ethnoscience knowledge on women and health, especially the benefits of herbal remedies for fertility, pregnancy, pre, and postnatal care. Furthermore, practice and belief integrate into modern medicine. The expression of such methods manifests in the cultural capital that views the healing process is integral. As a result, this ethnoscience phenomenon reinvents in a new commercial form that fits modern medicine as a way to rejuvenate women after childbirth.

Keywords: midwife, herbs, practice, traditional, modern 


\section{INTRODUCTION}

Women and childbirth are profound in the cycle of life, though their reproductive roles are often used by the state and market to discriminate women from an equal position, payment and benefit (Stamarski and Leanne 2015; Verniers and Vala 2018). Nevertheless, women and health are a captivating topic, and herbal remedy is massive market consumption for alternative medicines. The popularity of this alternative medicine is due to the belief that going back to nature will prevent or cure the disease away from unexpected side effects. This article is exploratory, and it attempts to share practical information about women and their reproductive role towards the process of care in traditional methods for maintaining their good health after childbirth. Moreover, this conventional method has been accommodative with modern medicine and relives the heritage of herbal remedy perpetually.

The sustainability aspect of the blended practice between traditional care and modern invention has an essential impact on the relevancy of ethnoscience towards modern medicine. This article argues that current practice has been able to keep alive the traditional method of attending women and health. This article rebuts the notion that becoming "modern" requires a transformation from traditional to contemporary in the form of leaving the classic elements (Inglehart and Welzel 2005; Martin 2015). The process of preserving the conventional method is a social construction that ingrained in the society through the belief system, cosmological principles and norms that value these attributes to be maintained and sustained. Thus, traditional and modern practices improve the well-being of women and society.

\section{ETHNOSCIENCE, CULTURAL CAPITAL AND THE PRACTICE}

The ancient Mayans, Aztecs and Egyptians had their traditional ways to attend women after childbirth. Women in the Mayan and Aztec civilisations were the symbol of fertility and balance in society (Aztec Gender Roles in Society n.d.). In ancient Egypt, women were treated equally to men except in occupation (Mark 2016). Their roles were compelling as a deity, clergy, healer or physician, and counsel apart from weaving, sewing, nurturing, and child-rearing (Mark 2016; Aguilar 2014). These redefining women roles in the ancient era were revealing in the archeological findings, including grave goods, artifacts and tools. In particular, these findings have been incorporated into gender theory and yielded new ways of interpreting the female roles in the Mayan and Egyptian cultures (Mark 2016; Aguilar 2014). 
Archaeologists from the University of Pennsylvania Museum have discovered a 3,700-year-old pair of magical birth brick inside the palatial residence of a Middle Kingdom mayor's house in southern Egypt (The University of Pennsylvania Museum of Archaeology and Anthropology 2002). The mud bricks would have been used to support a woman's feet while squatting during actual childbirth. In the ancient text, the standard form of delivery in ancient Egypt was for the woman to deliver the baby while squatting on two mud bricks. The ancient Egyptians believed that asking help from gods can be done through magical objects like birth bricks and particular ritual practices during childbirth. The birth brick was associated with a specific goddess named Meskhenet which was sometimes depicted in the form of a block with a human head. This discovery offers another piece of life story in ancient Egyptian society that gives a rare glimpse of the past into motherhood and childbirth. The dedication of archaeologists to share the interpretation of the Biblical text and artifacts would allow modern medicine to consider the squatting position as a way to reduce pain and as an easy exit for a baby. This ancient method proves that woman's roles as midwives are profound and valued.

Women's role as a healer is rich in preparing herbal ingredients for health remedy, and this practice of attending disease, ailment and childbirth is called ethnoscience. In other word, ethnoscience consists of the different ways the world is perceived and categorised in a different culture. Thus, the diverse culture and practices to health care may involve the element of cosmology, religion or spirituality, norms, and values as approaches to attend women and childbirth. This article argues that ethnoscience provides an avenue to appreciate alternative medicines that continue to dominate society's hope for preventing, attending, or curing ailments or diseases. In childbirth, the ethnoscience has stood against time, and such practices have survived the modernisation and millennium objectivity of science. Reasons for such resilience in practice are due to a few factors including inheritance of traditions that pass from generation to generation, the institutionalisation of knowledge in midwife's skills through informal training and education, the inclination of culture and norms for a healthy life, and reassurance of religion and belief for nature and remedies.

The factors, as mentioned above, are categorised as cultural capital. Bourdieu (1986) argues that the structure of the social word is an accumulation of history, and it must be continuous. Hence, cultural capital literally is an accumulation of labour in its objectified form that leads to an economic game. The capital within the economic interpretation led to the historical invention of capitalism defined as the maximisation of profit, self-interest, and trade and exchange. However, the social word does not account to the objectified form only, 
because the immaterial parts are the result of negative counterparts underpinning the economic activities - for example, the practice of midwives in encouraging new mothers to subscribe to traditional methods are driven by tradition that accumulated through self-experiences and witnesses among their patients, siblings and relatives who embraced it.

The reason for such categorisation being significant is, as Bourdieu (1984; 1986) opines, cultural capital includes both empirical and abstract elements. The former form includes consumption practices, while the latter is the embodied form that interprets in a phenomenological sense, which requires an interpretation of the way the people create meaning and expressions. The empirical or objectified state presents itself with the appearance of autonomy transcending in the individuals' will and action, and it may exist in the form of abstract elements like a symbol, active material (class struggles) and significant production (academic qualification, social credential, artistic sculpture, and paint or scientific innovation).

Chan (2017) argues that debates about the two camps over Bourdieu's cultural capital concepts are divided into two categories - the wild and domesticated themes (p. 6). She further updates that the embodied cultural capital must capture observation through individuals' values and ambition. Moreover, the categorisation of thematic outlines as the wild idea refers to the original version of Bourdieu which are embraced by scholars including DiMaggio (1982), De Graaf, De Graaf and Kraaykap (2000), Robinson and Garnier (1985), and Jonsson (1987). Cultural capital indicators are attitudes to culture and familiarity with cultural variables, including interest, philosophy, education, values and motivation that are nonnumerical elements but captured through practices, appearances and expression. The domesticated theme refers to Bourdieu's interpretation of converting the forms of cultural capital into empirical attributes. Scholars that supported this theme argue that cultural capital attributes consist of objectified elements such an individual's possession of books, participation in cultural activities including attending museums, theatre and art exhibitions (Graetz 1988; DiMaggio and Mohr 1985; Sullivan 2001; De Graaf, De Graaf and Kraaykap 2000).

Synthesising from Bourdieu's cultural capital, this research argues that through personal observation and experiences, the ethnoscience practices in the form of food consumption, health care processes and the reward of traditional herbal remedies are cultural capital that fits in Bourdieu's non-numerical interpretation of both empirical and abstract elements. The practical part was exhibited through the practices of pre and postnatal care, including the bathing technique, diets and body massages. The abstract components which converted into empirical attributes include the cosmological belief of foods being categorised as hot and cold, later such faith becomes the norms determined by midwives which are accepted, recognised and passed from generation to generation. 


\section{MIDWIVES AND THE LITERATURE}

The literature on midwives within the discipline of anthropology is outlined in various sources. Laderman $(1983 ; 1991)$ studied midwives' practices in Terengganu, Malaysia and furthered her analysis on the shaman practices or traditional method of healing other diseases than childbirth. Laderman's comprehensive review of midwives, women and birth remain the complete long-standing study for more than 30 years. In addition to Laderman, a few types of research on midwives in Malaysia retrieved include the midwives' institution during the colonial period of 1900-1955 (Azlizan and Suraini 2018); differing ethnic service and practice of midwives (Stuart 2014); the mystical belief (Wazir Jahan 1984) and midwives' opinions on postnatal depression (Keng 2005). Each of this research has its dimension and context that depart from Laderman's anthropological narrative of midwives' practices, healing technique and postnatal care.

The founding of hospitals in Malaya was a result of the British colonial occupation. The British started to build hospitals in the Straits Settlements in Singapore, Melaka and Pulau Pinang and later extended them to the other Federated Malay States. Hospitals were the result of economic growth that demanded the labourers' health to be productive in meeting the British quest for profit in the rubber, palm oil and tin mining industries. Although the idea of a hospital was to first serve the British and public officials, the extended services were necessary for the migrant workers because the influx simultaneously increased the populations and exposed them to many health issues. The growing colonial economic sectors demanded the British to supply healthy workers for their plantations, mines and agricultural businesses.

The British built hospitals in urban areas, mines and estates and the facilities used to serve both genders. For example, in 1919, there were 55 hospitals at the estates in Kuala Selangor district, and the total number of hospitals reached 120 in the 1920s (Azlizan and Suraini 2018, 18). Midwifery services were introduced at the hospitals in Selangor, but hesitation was high among the Malay women because traditional approaches embedded in their culture and belief system rejected the modern science. Furthermore, the traditional midwives were a group of senior women, highly respected for their healing skills, and their social status was profound as people who initiated most ritual events concerning women and their reproductive role, childbirth, marriages and fertility. The strong cultural belief had urged the British to approach the traditional midwives differently. They created a training programme for midwives and took recruits among young local women. They also offered a new status for traditional midwives who registered in the training programme. The certified midwives received a monthly salary, an additional allowance for those who attended five or six birth cases in a month, 
and subsidies for those who worked in rural areas (Azlizan and Suraini 2018, 19-24). The new institutionalised midwifery services by the British had set a modern standard for attending women and neonatal care.

The British method of define and rule according to racial criteria had influenced the hospitals and maternity services. ${ }^{1}$ The Chinese Maternity Hospital Kuala Lumpur and the Chinese Maternity Association had set diversity practices regarding women and childbirth. This association had helped the Chinese immigrants in the mining areas over their health care condition. Stuart (2014) argues that the diverse cultural background of the various races in Malaysia requires midwives to be conversant with the different racial beliefs and practices surrounding childbirth including multilingual skill, multi-racial integration, understanding and acceptance that will ensure women's needs are served respectfully.

Amid modern medicine and diversity of practices in midwifery, Wazir Jahan (1984) discusses the professional rivalry and dissonance amongst traditional Malay midwives in northwestern Peninsular Malaysia. The creativity of techniques, symbolic and ritual communications are crafted to develop client-patron relationship and trust. Additionally, the midwives hold skills and mystical force to diagnose particular curative rituals of spirit-possession limited to infant and children, young unmarried women and pregnant mothers. Competitions among midwives for such spiritual skills may surface in a competitive battle where the winner gradually wins over her clients. Here the code of professional ethics is determined by capabilities, experience, religious piety, wisdom and fair-play in winning the patrons. The government midwives are competitors to the traditionalist midwives, and the label placed upon them as practitioners of some witchcraft, conceived to be divergent, anti-Islam and destructive.

In another topic on midwives, Keng (2005) focuses on the Malaysian midwives' views of postnatal depression (PND) as a severe disorder that progresses imperceptibly and affects the quality of life of mothers, threatens the infants and the entire family. The survey was conducted amongst 57 midwives at the Maternity Units of Hospital Universiti Sains Malaysia (HUSM) on their knowledge and perception of PND. The results reveal that $50 \%$ of them are confused about PND with postnatal blues or unable to adjust to life after childbirth delivery. More than $17 \%$ of midwives support that PND health education and awareness programmes are vital for them. Consequently, the low response rate among midwives at HUSM is related to their lack of knowledge of PND. Thus, Keng (2005) in her paper, highlights the need to train midwives at HUSM and Malaysia for them to identify mothers at risk of, or experiencing such depression behaviours. The Malaysian Midwives Act of 1966 states the necessity for midwives to fulfill their roles, including training them to be skillful in their 
profession. Therefore, the growing demand for understanding PND content is necessary.

Meanwhile, other available researches on midwives outside Malaysia are from Mexico, Turkey, Europe, United Kingdom (UK) and North America. Jordan (1989) conducted comprehensive research on the training of traditional midwives in Yucatan, Mexico. The study provides in-depth insights on the transmission of knowledge and skills in Mexico's hierarchical society. The training programme for midwives is vital to ensure that the sound knowledge of modern medicine will be accepted in the social system because local midwives will continue to assist women for child labours for decades to come. The ethnoscience aspect in the traditional midwifery integrates into human life before modern science, and the vitality is still significant.

Moreover, the living tradition related to healthcare before childbearing, during pregnancy, a method to help women through labour, pre and postnatal care are critical in most cultures in this world (Okka, Durduran and Kodaz 2016, 501). Modern healthcare is improving the traditional method rather than rejecting it. The ethnoscience concept has allowed the technique of caring for women's health to be established based on local wisdom and resources. Furthermore, Okka, Durduran and Kodaz (2016) argue that traditional folk medicine in Turkey consists of practices utilised for centuries and transmitted from generation to generation (p. 501). The ethnoscience of traditional methods developed and integrated with modern medicine in most of Turkey.

Consequently, both positive and negative implications can be viewed based on the record retrieved from the hospital. Thus, the favourable implication includes the healing process using the herbal remedy, while the severe consequence consists of the delaying diagnosis or treatment for complicated childbirth such as breech, or ectopic pregnancy. These complicated pregnancies need a modern $\mathrm{x}$-ray to scan and to proceed with proper treatment.

Furthermore, Okka, Durduran and Kodaz (2016) describe that in Turkey, the Anatolian society has various traditional herbal remedies used for vaginal suppositories, especially after childbirth (pp. 503-504). The magical beliefs of visiting entombed saints, making vows, or bathing in thermal springs would be beneficial for women to conceive faster. Herbal remedies such as blackberries, mallow, cloves, black seeds, nettle seeds and rhubarb mixed with honey are food for fertility. The society in Anatolian culture believes that having a child ensures the continuity of the family and strengthens women's status and value in the community. On the contrary, inability to bear a child may lead to difficulties and even dissolution of marriage. Women often get blamed for being barren and men who go for fertility consultation are looked down upon. Similar to Malaysia, such description matches views that both women and men have reproductive issues. Even in modern times, such assessment prevails. 
Okka, Durduran and Kodaz (2016) continue to delineate the ethnoscience practices in Turkey that during pregnancy the traditional folk believes that whatever a pregnant woman desires or craves for has to be fulfilled (pp. 505-508). Such belief connects to nutrition, and if such a demand is unfulfilled, then the baby might have a deficiency. Foods consumed by pregnant women are believed to affect the sex of the baby too. If a pregnant woman desires acidic food or fruit, she will give birth to a girl and if she wants sweet food, she will bear a boy. Furthermore, the 40 days prohibition imposed on women and care for a newborn baby are still favoured as a ritual to give special care and attention. This confinement manifests caring a reflection of hope that the mother and baby will be healthy, healed, and protected from the evil spirit. In Turkey, the traditional practices before and during pregnancy, pre and postnatal care in different regions are kept alive until today. The modern method of midwives blends into the conventional ethnoscience and both approaches assist gender well-being in society.

Najla, Richter and Farida (2013) discuss another interesting literature on midwives and ethnoscience. They did a categorisation of historical analysis through different eras to outline the traditional practices that turned modern after a series of evolutionary changes. The first category was the Byzantine era of $400 \mathrm{AD}-600 \mathrm{AD}$ that discussed the institutionalisation of midwifery practices. Moreover, Islamic civilisation had built infrastructure for public health care such as hospitals and empowered women's role in midwifery. Thus, the culture itself had maintained women-centred functions to sustain growth in society. Nevertheless, access to education and training favoured men over women, which undermined opportunities for women to further their studies in healthcare services and pursue their career as midwives. Despite rigidity of access to women, the Islamic civilisation era exhibited a relatively organised, competent, and standardised healthcare system (Grant and Carter 2004; Towler and Bramall 1986).

The second category was the dark ages and middle ages era of the 5th to the 15th century. During this medieval period, the roles of Christianity and churches were dominant, and midwifery was valued and religiously respected. Nuns' practice midwifery as a religious obligation, and they were known as female occupational doctors. They care for women, such as assessing and managing pain during labour, maintaining hygiene and the comfort status for a mother and her newborn. However, in the later middle ages throughout the UK, Europe and North America, midwives were marginalised and excluded. Many female midwives were barred and burnt at the stake following accusations of witchcraft (Towler and Bramall 1986). The authority defined by the medieval church suppressed women and gave way for men to be physicians. Thus, gender inequalities had prevented women from functioning as midwives and gain formal education during this era.

The third category was the modern era of the 17th century to the 18th century. This modern era witnessed the booming of surgical instruments and 
institutional medical training that introduced males in midwifery. For instance, barber-surgeons known as forceps-man attended many difficult birth and hopeless cases (Najla, Richter and Farida 2013, 118). Although they were controversial and questionable at the onset and men-wifery were labeled as improper, deviant and scandalous, the social perspectives changed tremendously due to subsequent demonstrations of male skills in assisting women during child labour. As a result, the classification system was designated for women as midwives and men as obstetricians (Evenden 2000). Later, men became privileged and received formal education for medicine.

Finally, the fourth category is the present period and a regulated profession in the UK and Europe. The nursing profession is very demanding in the UK and Europe. To ensure such job is reliable and recognised, many bills are introduced to regulate nursing as a regulated profession compared to midwifery. The objective is to maintain public safety and protection against any harmful practices. A few law and regulations were established in the UK, especially the Midwifery Act of 1952 and the Central Midwives Board (CMB). The Royal College of Obstetricians and Gynecology is the appointed body as a co-supervisor regulatory body in CMB. The act allows skills offered with the certification of competence such as the Midwifery Teacher Diploma Examination and the Midwifery Teachers Training College. Over the years, increasing numbers of women have attended this training.

\section{THE THEMATIC ANALYSIS}

This exploratory study applies unstructured interviews with four midwives in Perlis, Kedah, Pulau Pinang and Selangor. The midwives have more than 20 years of experience each attending pre and postnatal care. Most of these respondents were midwives at the public hospitals and continued to serve as midwives after pension. The narratives from these interviews were transcribed and a thematic analysis was developed to see the patterns of processes, ingredients, reasons and technique. Although these midwives did not know each other due to spatial distances, interestingly most of them shared similar perspectives in caring for women before and during pregnancy, pre- and post-delivery.

The interviews were conducted for three months and the purposive sampling was applied due to the nature of this research that purposely chose midwives as the respondents for their experience, skills and knowledge of traditional norms and herbs. The saturation process reached four respondents because the third and the fourth interviews did not yield any new information that differed from the previous two respondents. For this thematic analysis technique, intensive discussions provide an excellent conversational analysis to capture how people construct their realities and highlight their points of view through description and 
explanation of their own experiences (Coulon 1995; Taylor and Bogdan 1998; Schutt 2015). The same unstructured, open-ended descriptive questions were shared to all respondents that enabled them to talk about their favourite topics without structuring what the responses should be. Free-flowing dialogues and effective probing techniques applied during the interviews. Furthermore, repeated face-to-face encounters were conducted to understand respondents' perspectives and personal experiences as midwives. Interview statements were taped and transcribed.

Themes and unifying concepts were developed based on words and recurring conversational topics. The identifying themes, constructing typologies and relating different pieces of data to each other allowed this research to uncover the practice of traditional methods in attending women before and during pregnancy, pre and postnatal care. The recurring topics and emphasis are described and clarified according to the themes categorised as bath, diet and body massage. Each category outlines the herbal remedies used for fertility, pregnancy, pre and postnatal care - a full description of these themes is displayed in Table 1 and Appendix. The development of themes allows the gist from the interviews' transcriptions to be outlined convincingly and simultaneously to avoid having an unnecessary list of conversations. The participant observation and interviews resulting from this research will not be used for generalising the study of midwifery and midwives, but the findings can be referred to as significant because they provide empirical evidence that the traditional method, herbal remedy, religious belief and cosmological view defined as ethnoscience remains pivotal in Malay society.

\section{FOODS FOR PRENATAL CARE}

Most respondents share pretty much similar ideas on meals for prenatal care and during pregnancy. The overall perspective on prenatal foods is that a woman must prepare herself physically and mentally to be a mother. Foods with rich vitamins, minerals and nutrition are good for fertility. Those vitamins and minerals will help women to conceive better. A woman must eat and simultaneously enriches the body and soul. Enriching the soul through foods can be done by tracing back to the practice of saying prayers before eating because it is believed that the prayers would help to revive and to rejuvenate the system inside a person spiritually. The consuming foods in physical form can thrive better with prayers because the idea of being healthy inside and out is also to nurture the soul through good healthy meals.

The traditional approach to foods is divided into two categories, namely edible and non-edible foods. The right consumable type remains full and open, but 
none of the midwives mentioned the need for a balanced diet. Additionally, the midwives do not categorise foods based on the colonial knowledge of balanced diets such as carbohydrate, protein, vegetables and fruits, and sweets. On the contrary, they believe that a pregnant woman can eat almost everything at her desire. Based on their experience, most women struggle very hard in their first trimester due to the changing hormones, while some have better tolerance for their new addition. It is difficult for most women to keep up with a well-balanced diet, some may develop an awkward eating habit. Thus, the term mengidam or craving is allowing all her needs or desire for foods to be fulfilled, or else they believe that the baby will be born with excessive drooling or saliva.

The non-edible category is everything defined as "cold food". "Cold foods" must be avoided during pregnancy because these foods are believed to cause a bloated stomach, sore muscle and joints, and possible jaundice to mother or baby once born although their perspectives challenge the scientific basis; the idea of avoiding certain foods being based on their long-life experience as midwives. Nowadays, women with modern lifestyles are unlikely to follow the food restriction because of too rigid requirements and absence of scientific reason. However, there will be some people that are likely to follow the traditional method.

Furthermore, these midwives are concerned with the modern trend of eating fast foods or canned food loaded with artificial colour or preservatives that are available on the market. Besides, they assume that this is the reason for most newborn babies in this modern day likely to have contracted jaundice. Another interesting fact is, these midwives believe that these foods are most problematic because of the chemical substances that can be found in cans or fast food that could cause a Ripley effect in the long run especially to women when they reach their pre-menopause period or during their golden years. The underlying perspective is that a mother who eats healthy food and avoids eating foods categorised as "cold food" would be in an excellent physical condition to give birth to a healthy baby and also allows her body to heal fast during the confinement period.

Based on Table 1, midwives have their ways of applying the bath, the diet and terms of massage, but they share many similar local herbs for postnatal care. Most of them have been midwives for over 20 years and share almost the same pattern of restrictions, especially towards cold foods and the intake of liquid. The findings shared the perspectives discussed by anthropologist Carol Laderman in her book Wives and midwives: Childbirth and nutrition in rural Malaysia, back in 1983. Laderman conducted her study in Terengganu. The details of her research include the conduct of postpartum care, including the massage with roasting bed and bertungku stone, the ritual for shaving the baby hair, purifying bath, and the circumcision process. In terms of foods, Laderman (1983) was detailed on the food restrictions, namely the hot and cold foods, but absent from her account was the herbal remedy used for postnatal care (pp. 183-188). 
Laderman published her book in 1983 and based on the current fieldwork, the traditional practice is still ongoing. These midwives are in their seventies and had served the community from the 1970s or early 1980s. Based on the interviews, the explanation for the continuity of the practice is shown in four ways. First, three of the midwives (Pulau Pinang, Kedah and Perlis) became midwives based on their family inherited tasks and a divine assignment by God. The inheritance applies to their daughters, daughters of other siblings, and daughters of close relatives. As long as the bloodline of midwife runs in the family, anyone from the same family tree will have the chance to be selected as a midwife. The appointment declared through a dream or any paranormal activities encountered by a person later builds her persona and ability to deal with factual and mystical phenomena. Laderman (1983) proved that the food taboos during the postpartum period had been handed down from one generation to another, and these taboos were religiously followed. Therefore, this study believes that as long as the embedded Islam with layers of traditional Malay custom are practiced, the conventional postnatal care will survive for years to come.

Second, a midwife from Rinching, Selangor shared her story that she became a midwife through modern and traditional training. As a nurse who worked in the General Hospital of Kuala Lumpur, she began her formal training as a nurse in the hospital and added the understanding of the traditional approach to postnatal care at a place in Kepong way back in 1979. She learned this conventional method along with a few other ladies (five to six people) whom she considered as her batch friends. They were disciples who were trained to be the healer of cases of sprained ankle, bloated tummy, postnatal massage, and they were required to memorise surah from the al-Quran to begin the healing process.

Third, the tradition of herbal remedy, the list of do's and don'ts, and the method of bertungku passed from one generation to another, and the flow blended in the health institutions, be it private or public hospitals. For example, the private health care providers, namely Hospital Islam Az-Zahrah and An-Nur Specialist Hospital both provide women health facilities and spa with traditional methods for healing purposes. The public hospitals like Hospital Kuala Lumpur, Hospital Universiti Kebangsaan Malaysia and Pusat Perubatan Universiti Malaya also provide information on postnatal care and do not prohibit the traditional approach. Additionally, traditional herbs are healthful and not regulated as drugs. Although the dichotomy between herbs and drugs is debatable and herbs may be harmful to consumers (Novella 2013), the list of herbs mentioned in this study proves to be non-toxic as most of the herbs are used in daily cooking such as lemongrass, galangal, turmeric, garlic and ginger. 
Fourth, the current consumption has invented an easy way for the consumers to use these herbs in a form of pills, liquid, juice drink, paste, rubit-on oil or cream that are used efficiently. The mass production of herbs is now available in the market with different names and labels such as Syamilati, Nona Roguy, Mustika Ratu, D’Herbs, Sendayu Tinggi, Anugerah, and Nyonya Meneer. Thus, the new invention of traditional herbs into modern consumption products will further sustain the traditional beliefs and practices for generations. The sustainability impact is accelerated further with the acceptance of traditional herbs into recent innovation of foods supplements. The substantial advantages of these herbs are by millions of women in Malaysia, Indonesia, Singapore and Brunei, where the traditional Malay Archipelago influence is profound.

Furthermore, Laderman (1983) provided a detailed explanation that rejecting the Malay tradition of food restriction during the postpartum period might be the primary cause of maternal ill health (pp. 190-201). She conducted the blood and serum nutrient analysis of nine different respondents who gave birth that followed various postpartum periods of 40 days, 20 days and 14 days and from the restricted diet to those who never limit their foods. The malnutrition was due to poverty rather than ideological restriction. Those who can afford to buy meat and poultry will have a varied menu on their diet. In tandem with this previous finding, all midwives agree that postpartum diet restriction is meant to heal women's reproductive asset to its prime healthiness, and this is vital for women as a wife, mother and community builder. 


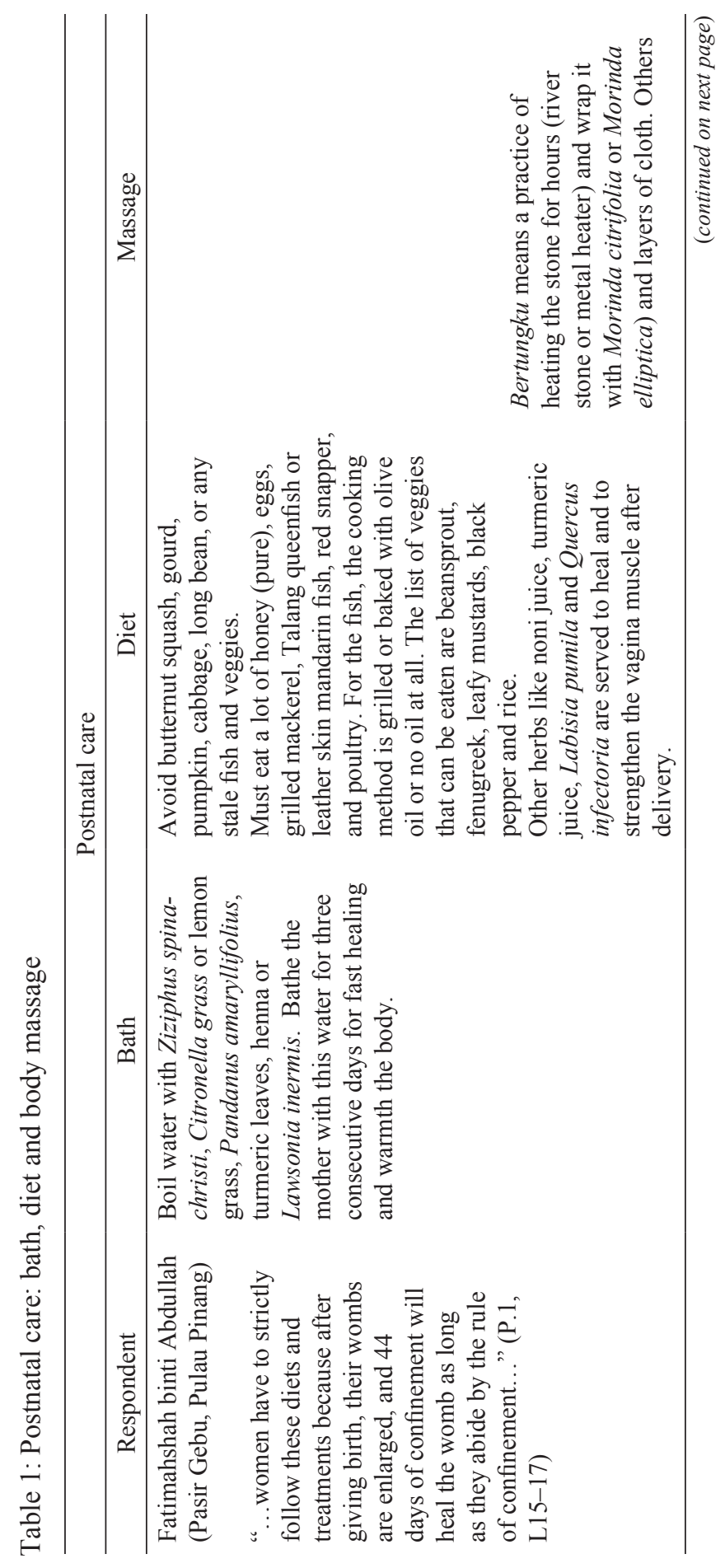




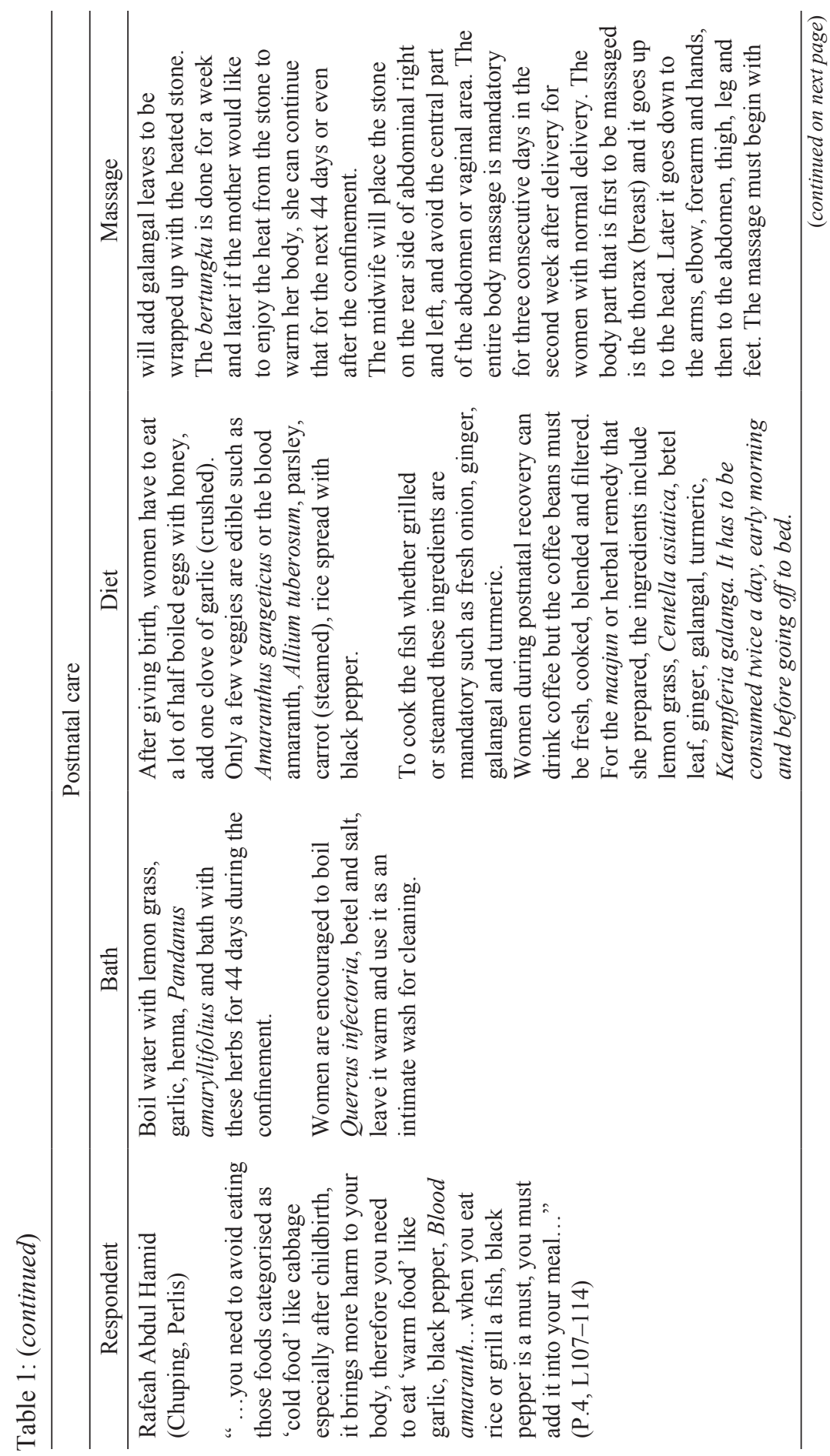




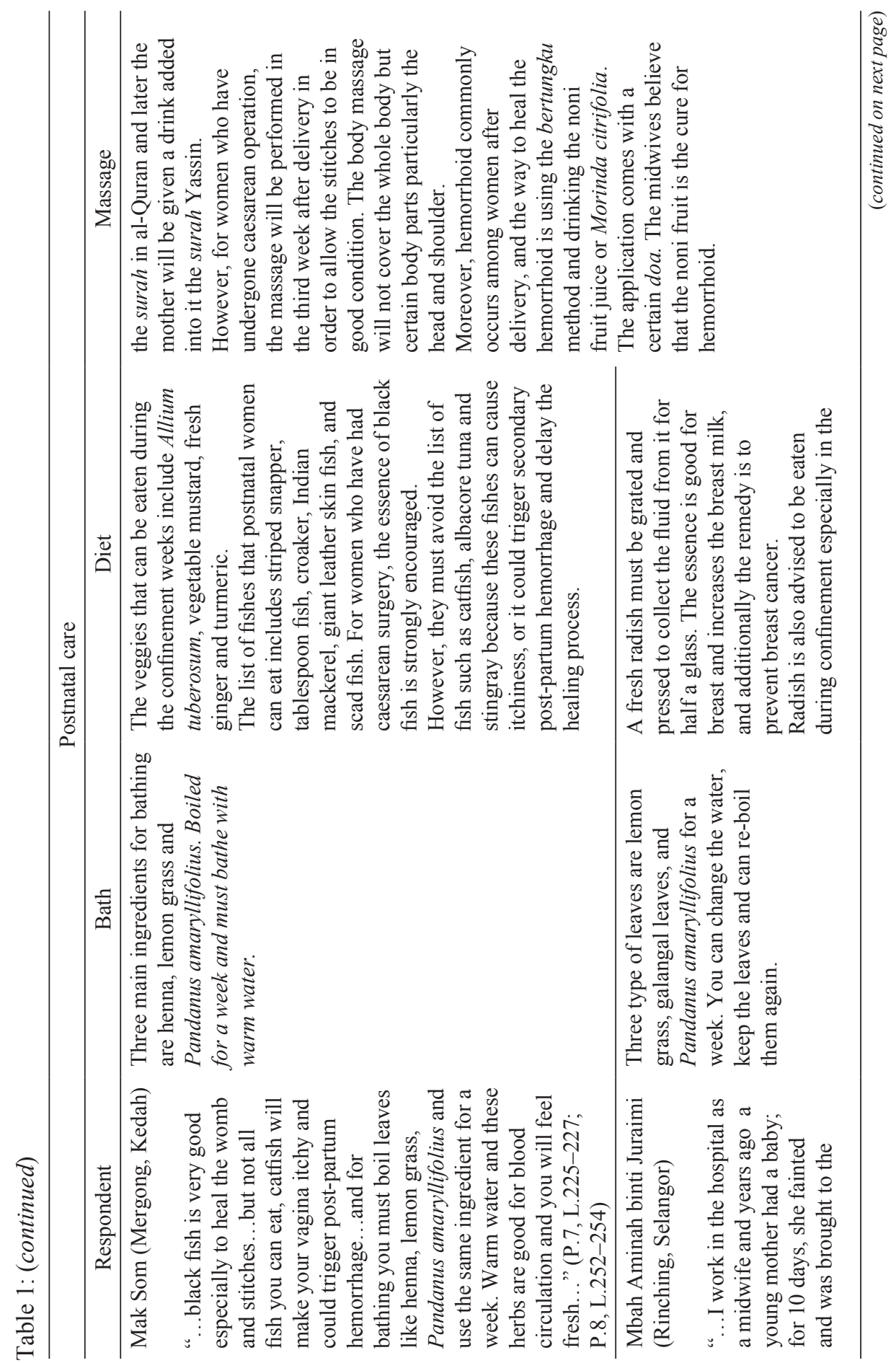


Midwives and Herbal Remedies

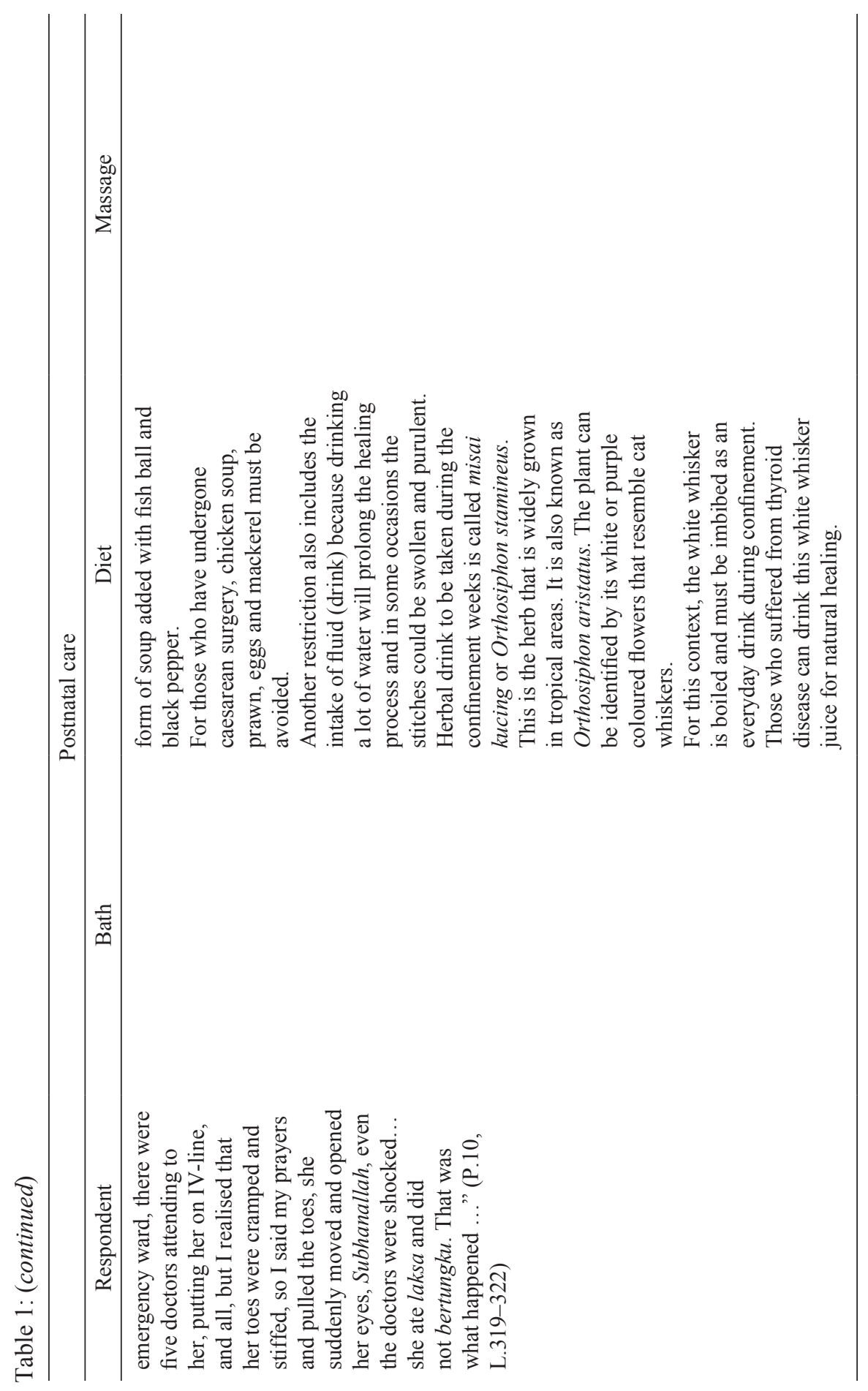




\section{CONCLUSION}

The study of food and postnatal care invites a new discussion on the manner of traditional health care in society, especially the utilisation of herbal remedy. The Malays have their ways of preserving the health of a mother after childbirth. The traditional terms are different from the pathogenic of colonial medicine that requires the evidence of empirical scientific data. However, the former is accepting and acknowledging the modern-day medicine as necessary for women's vitality. Both approaches and practices are complementing one another and will continue to benefit women psychologically and physically. As a result, ethnoscience through traditional methods combined with modern practices is the growth and sustainability context that allows the society to retain their belief and social existence. The modern acceptance of the traditional approach is a rebuttal of the basic idea that modernisation's assumes that transformation from traditional to modern removes or leaves the metaphysical world for tangible scientific practices. The integration for the sustainability of practices from conventional to contemporary life evolves and fits according to local wisdom, belief system and traditional cosmological principles.

\section{ACKNOWLEDGEMENTS}

Authors would like to acknowledge the research grant code GGPP2017-008 and DCP-2017-009/1 from Universiti Kebangsaan Malaysia for making this research achievable.

\section{NOTE}

1. The method of define and rule by the British resulted in a longitudinal impact. Such policy action was meant to ease the British in managing the plural society by giving each of them single labels that hid their intra-ethnic identity and dialects. For instance, the Malay was one such label that collapsed ethnic groups such as Semai, Kanak, Bugis, Mandeling, Banjar; Chinese [consisting of Cantonese, Hakka, Hokkien]; Indian [consisting of Tamil, Telegu, Malayali, Sinhalese]. The distinctive definition or categorisation had allowed the British to differ between settlers and natives. (See Mahmood Mamdani, Define and Rule: Native as Political Identity (USA: Harvard University Press, 2012). 


\section{APPENDIX}

\section{The list of names of herbs/vegetables used in postnatal care}

\begin{tabular}{|c|c|c|}
\hline No. & Names of herbs/vegetables & Details \\
\hline 1. & Misai kucing & $\begin{array}{l}\text { Orthosiphon stamineus is a herb that grown wildly } \\
\text { in tropical areas. It is also known as Orthosiphon } \\
\text { aristatus. The plants identified by its white or purple } \\
\text { coloured flowers that resemble cat whiskers. }\end{array}$ \\
\hline 2. & Mengkudu besar & Morinda citrifolia \\
\hline 3. & Mengkudu kecil & Morinda elliptica \\
\hline 4. & Buah mengkudu & Noni (cheese fruit Morinda citrifolia) \\
\hline 5. & Daun inai & Henna or Lawsonia inermis \\
\hline 6. & Daun pandan & $\begin{array}{l}\text { Pandanus amaryllifolius. Pandanus amaryllifolius is } \\
\text { a tropical plant in the Pandanus (screw pine) genus, } \\
\text { which is commonly known as pandan leaves } \\
\text { (/'pændən, livz/) and is used widely in South Asian } \\
\text { and Southeast Asian cooking as a flavouring. }\end{array}$ \\
\hline 7. & Serai wangi or lemongrass & $\begin{array}{l}\text { Cymbopogon nardus, common name citronella grass, } \\
\text { is a perennial of the Poaceae grass family, originating } \\
\text { in tropical Asia. It is the source of an essential oil } \\
\text { known as "citronella oil." }\end{array}$ \\
\hline 8. & Lengkuas & $\begin{array}{l}\text { Alpinia galanga, (also Languas galanga), a plant in } \\
\text { the ginger family. }\end{array}$ \\
\hline 9. & Daun lengkuas & Alpinia galangal leaf \\
\hline 10. & Daun seringan atau meringan & Ziziphus spina-christi \\
\hline 11. & Manjakani & Quercus infectoria \\
\hline 12. & Pegaga & $\begin{array}{l}\text { Hydrocotyle asiatica (Centella asiatica); A creeper } \\
\text { and herbaceous plant. }\end{array}$ \\
\hline 13. & Kacip Fatimah & Labisia pumila \\
\hline 14. & Biji kopi & Robusta or C. arabica \\
\hline 15. & Halia & Ginger (Zingiber officinale) \\
\hline 16. & Kunyit & Turmeric (Curcuma longa) \\
\hline 17. & Lengkuas & Galangal (Alpinia galanga) \\
\hline 18. & Ikan haruan & Black fish (Channa striata/snakehead murrel) \\
\hline 19. & Ikan duri & Arius sumatranus \\
\hline 20. & Lada hitam & Black pepper (Piper nigrum) \\
\hline 21 & Bawang merah & Red onion (Allium cepa) \\
\hline 22. & Bawang putih & Garlic (Allium sativum) \\
\hline
\end{tabular}




\begin{tabular}{cll}
\hline No. & Names of herbs/vegetables & Details \\
\hline 23. & Cekur & $\begin{array}{l}\text { Kaempferia galangal commonly known as kencur, } \\
\text { aromatic ginger is a monocotyledonous plant in the } \\
\text { ginger family. } \\
\text { Red snappers (Lutjanus campechanus) }\end{array}$ \\
24. & Ikan merah & Amaranthus gangeticus or the "blood amaranth" \\
25. & Bayam merah & Allium tuberosum or Allium odorum \\
26. & Kucai & Parsley (Petroselinum crispum) \\
27. & Daun sup & Betel leaf (Piper betle) \\
28. & Sireh &
\end{tabular}




\section{REFERENCES}

Aguilar, L. 2014. Redefining the past: Women in classical Mayan culture. https://scholarscompass.vcu.edu/cgi/viewcontent.cgi?article=1090\&context =ures posters (accessed 15 December 2017).

Aztec Gender Roles in Society. n.d. Female role. https://genderrolesaztec.weebly.com/ female-role.html (accessed 15 December 2017).

Azlizan Mat Enh and Suraini Rosli. 2018. Institusi Perbidanan di Selangor, (1900-1955). Akademika 88(1):17-34. https://doi.org/10.17576/akad.2018-8801-02

Bourdieu, P. 1984. Distinction: A social critique of the judgment of taste. Massachusetts: Harvard University Press.

1986. The forms of capital. In Handbook for theory and research for the sociology of education, ed. J. Richardson, 241-258. Westport CT: Greenwood. http://www.socialcapitalgateway.org/sites/socialcapitalgateway.org/files/data/ paper/2016/10/18/rbasicsbourdieu1986-theformsofcapital.pdf (accessed 7 April 2018).

Chan, R.S.K. 2017. Ah Beng subculture and the anti-capital of social exclusion. UKM Ethnic Studies Paper Series No. 54 (August). Selangor: Institute of Ethnic Studies, Universiti Kebangsaan Malaysia.

Coulon, A. 1995. Ethnomethodology. Newbury Park, California: Sage Publication. https://doi.org/10.4135/9781412984126

Davis, I. 2009. The new normal. McKinsey Quarterly. http://www.mckinsey.com/insights/ strategy/the_new_normhttp://www.mckinsey.com/insights/strategy/the_new normalal (accessed 3 October 2017).

De Graaf, N.D., P.M. De Graaf and G. Kraaykap. 2000. Parental cultural capital and educational attainment in Netherlands: A refinement of the cultural capital perspective. Sociology of Education 73(2): 92-111. https://doi.org/10 $.2307 / 2673239$

DiMaggio, P. 1982. Cultural capital and school success: The impact of status culture participation on the grades of US high school students. American Sociological Review 47(2): 189-201. https://doi.org/10.2307/2094962

DiMaggio, P. and J. Mohr. 1985. Cultural capital educational attainment and marital selection. American Journal of Sociology 90(6): 1231-1261. https://doi.org/10 $.1086 / 228209$

Evenden, D. 2000. The midwives of seventeenth-century London. London: Cambridge University Press.

Graetz, B. 1988. The reproduction of privilege in Australian education. British Journal of Sociology 39(3): 358-376. https://doi.org/10.2307/590483

Grant, T. and S. Carter. 2004. Women in medicine: A celebration of their work. Canada: Firefly Books.

Inglehart, R. and C. Welzel. 2005. Modernization, cultural change and democracy: The human development sequence. UK: Cambridge University Press.

Jonsson, J.O. 1987. Class origin, cultural origin, and educational attainment: The case of Sweden. European Sociological Review 3(3): 229-242. https://doi.org/10.1093/ oxfordjournals.esr.a036451 
Jordan, B. 1989. Cosmopolitical obstetrics: Some insights from the training of traditional midwives. Social Science \& Medicine 28(9): 925-944. https://doi.org/10 $.1016 / 0277-9536(89) 90317-1$

Keng, S.L. 2005. Malaysian midwives' views on postnatal depression. British Journal of Midwifery 13(2): 78-86. https://doi.org/10.12968/bjom.2005.13.2.17465

Laderman, C. 1983. Wives and midwives: Childbirth and nutrition in rural Malaysia. USA: University of California Press.

1991. Taming the wind of desire: Psychology, medicine, and aesthetics in Malay shamanistic performance. USA: University of California Press.

Mahmood Mamdani. 2012. Define and rule: Natives as political identity. USA: Harvard University Press. https://doi.org/10.4159/harvard.9780674067356

Mark, J.J. 2016. Women in ancient Egypt. https:/www.ancient.eu/article/623/women-in -ancient-egypt/ (accessed 15 December 2017).

Martin, K.C. 2015. Readings in social theory and modernization. USA: Boston University College of General Studies, Massachusetts.

Najla Barnawi, S. Richter and Farida Habib. 2013. Midwifery and midwives: A historical analysis. Journal of Research in Nursing and Midwifery 2(8):114-121.

Novella, S. 2013. The science medicine: Herbs are drugs. Skeptical Inquirer 37(2). http://www.csicop.org/si/show/herbs_are_drugs (accessed 18 April 2017)

Okka, B., Y. Durduran and N.D. Kodaz. 2015. Traditional practices of Konya women during pregnancy, birth, postpartum period and newborn care. Turk J Med Sci 46: 501-511. https://doi.org/10.3906/sag-1504-120

Robinson, R.V. and M.A. Garnier. 1985. Class reproduction among men and women in France: Reproduction theory on its home ground. American Journal of Sociology 91(2): 250-280. https://doi.org/10.1086/228277

Schutt, R.K. 2015. Investigating the social world: The process and practice of research. 8th ed. Canada: Sage Publication Inc.

Skye, A.D. 2010. Aboriginal midwifery: A model for change. Journal de la Santé Autouchtone, Janvier 6(1): 28-37.

Stamarski, C.S. and S.S.H. Leanne. 2015. Gender inequalities in the workplace: The effects of organizational structures, processes, practices, and decision makers' sexism. Front Psychol 6: 1400. https://doi.org/10.3389/fpsyg.2015.01400

Stuart, C.C. 2014. Midwifery service and practice in Malaysia. British Journal of Midwifery 4(5). https://doi.org/10.12968/bjom.1996.4.5.245

Sullivan, A. 2001. Cultural capital and education attainment. Sociology 35(4): 893-912. https://doi.org/10.1017/S0038038501008938

Taylor, S.J., and R. Bogdan. 1998. Introduction to qualitative research methods: A guidebook and resource. New York: John Wiley and Sons, Inc.

The University of Pennsylvania Museum of Archaeology and Anthropology. 2002. Penn Museum archaeologists uncover 3700 year old "magical" birth brick at mayor's residence just outside Abydos, Egypt. 2002. https://www.penn .museum/old/information/press-room/press-releases-research/985-penn -museum-archaeologists-uncover-3700-year-old-qmagicalq-birth-brick-at -mayors-residence-just-outside-abydos-egypt (accessed 14 December 2018). 
Towler L, and J. Bramall. 1986. Midwives in history and society. London: Croom Helm.

Verniers, C. and J. Vala. 2018. Correction: Justifying gender discrimination in the workplace: The mediating role of motherhood myths. PLOS ONE 13(7): e0201150. https://doi.org/10.1371/journal.pone.0201150

Wazir Jahan Karim. 1984. Malay midwives and witches. Social Science and Medicine 18(2): 159-166. https://doi.org/10.1016/0277-9536(84)90036-4 